\title{
空間選択性に立脚した単結晶金属酸化物ナノワイヤの創製と ナノ物性・機能デバイス
}

\author{
柳田 剛・長島 一樹 \\ 九州大学 先導物質化学研究所 焉 816-8580 福岡県春日市春日公園 6-1 \\ （2017 年 3 月 11 日受付；2017 年 4 月 9 日掲載決定）
}

\section{Fabrication of Single Crystalline Metal Oxide Nanowires Based on Spatial Selectivity of Molecules and Their Nanoscale Physical Properties and Functional Devices}

Takeshi YanAGIDA and Kazuki Nagashima

Institute for Materials Chemistry and Engineering, Kyushu University, 6-1 Kasugakoen, Kasuga, Fukuoka 816-8580

(Received March 11, 2017 ; Accepted April 9, 2017)

\begin{abstract}
Here we report our recent progress as to single crystalline metal oxide nanowires towards the nano-device applications. As the basis of such fundamental science, we focus on (1) formation technology of highly crystalline nanowires, (2) evaluation technology of single nanowire physical properties, and (3) control of spatial nanowire positions. Especially, I focus on our recent progress of our research group, which are related to single crystalline nanowires comprised of functional metal oxide materials and their memristive devices.
\end{abstract}

KEYWORDS : nanowires, metal oxides, single crystallinity, functional properties, nanodevices

\section{1.はじめに}

単結晶構造の優れた物性機能を基板表面上に展開する 新しい科学技術が注目されている。従来は, 格子整合性 の制限から単結晶の機能物性を展開することが不可能だ と考えられてきた機能性材料群が様々な場（基板上）で デバイス化することが可能になりつつある。その有望な 単結晶ナノ構造の一つがナノワイヤである ${ }^{1,2)}$ 。基板と のきわめて微小な接合面積が薄膜構造では不可能であっ た格子整合性の限界を打破することを可能にしている。 代表的なナノ材料であるナノ粒子やナノシートと比較し ても，単結晶ナノワイヤ構造では基板上で金属電極との 接合が比較的容易であり, 線幅をナノスケールで微細化 可能であるという特徵を有する。加えて, (1)高品質な単 結晶半導体ナノワイヤ形成技術, (2)単一ナノワイヤ物性 評価技術，(3)ノワイヤ空間配列制御に関する新しい科

\footnotetext{
†第 36 回表面科学学術講演会（2016 年 11 月 29 日～12月 1 日）にて発表

E-mail : yanagida@cm.kyushu-u.ac.jp
}

学技術の目覚ましい進展がこれらの新しい展開を支えて いる。本稿では, 多種多様な機能物性を示す金属酸化物 材料から構成される単結晶ナノワイヤを形成し, 新しい 機能性ナノデバイスへと展開する筆者らの最近の研究成 果（1）酸化物単結晶ナノワイヤの形成技術 ${ }^{3 \sim 9)}$, (2)単一 ナノワイヤの物性評価技術 ${ }^{10 \sim 19)}$, (3)酸化物ナノワイヤ の機能デバイス展開一メモリス夕 ${ }^{10 \sim 16)}$ ・熱電変換 ${ }^{19)}$ ・生 体分子分離 ${ }^{2023)}$ ・分子センサ ${ }^{24)}$ ) を紹介する。

\section{2. 空間選択性に立脚した単結晶金属酸化物ナ} ノワイヤの創製

一次元ナノワイヤ構造を形成するためには, 気相中, 液相中の合成プロセスにおいて，1 方向に選択的に結晶 成長が発現することが不可欠である。しかしながら, 過 去の報告がある例や偶発的に形成する例を除けば，所望 の機能材料を自在にナノワイヤ構造化にすることは不可 能に近い。これは, 一次元ナノワイヤ構造形成に関する 普遍的な設計概念が存在していないことに起因してい る。たとえば, 気相法で基板上に供給された原子・分子 
は表面積を最小化する平面薄膜構造を容易に形成する が, 1 次元ナノワイヤ構造はきわめて “特殊な条件”で のみ形成される。ナノワイヤ研究の難しさ（面白さ）の 一つはこの 1 次元結晶成長が生じる “特殊な条件”を探 し出すことにある。無機ナノワイヤ研究の歴史を紐解け ば, 結晶構造自体に異方性がある材料系では（代表例： $\mathrm{ZnO}$ 等), 比較的その “特殊な条件” の範囲は広く, 数 多くの研究報告がある ${ }^{1)}$ 。一方で, 結晶構造の空間対称 性が高い物質の場合, その “特殊な条件”を見つけ出す のはきわめて難しい。

結晶構造に依存せずに 1 次元ナノワイヤ構造を実現す る有力な手法が Vapor-Liquid-Solid 法（VLS）である。 VLS 法では金属触媒を介して固液界面のみに空間選択 的に 1 次元の結晶成長が実現される。60 年代に米国べ ル研のワグナーらが金触媒を介したシリコンの単結晶ナ ノワイヤを発見し, その形成起源をVLS 法と命名した ことが発端となっている2)。この結晶成長法の特徴は, (1)空間の狙った位置のみに絶対選択的に所望の材料だけ で構成される非常に高品質な単結晶ナノワイヤを形成す ることが可能であること（多結晶ナノワイヤは形成不可 能)，(2)金属触媒の大きさを制御することで狙いのサイ ズ (径) のナノワイヤを設計できること, (3)供給する材 料を変更することで, 軸方向・半径方向に異なる材料が 積層された所謂 “へテロ構造” が実現可能であることが あげられる。これらの特徴を持ったナノワイヤを他のナ ノワイヤ形成手法を用いて設計することはきわめて困難 である。このように VLS 法は大変優れたナノワイヤ形 成法として注目を集めてきたが, 三相に跨る複雑な物質 移動を理解することが難しいために, 狙いの機能性材料 (たとえば，金属酸化物材料）をVLS 法を介してナノワ イヤ構造化することは困難であった。

酸化物ナノワイヤ研究を開始した当初 (2003 年), な ぜVLS 法を介して形成可能な金属酸化物材料種は大き く制限されているのだろうかという疑問を持った。文献 を調查すると, VLS 法を介して容易に形成可能な金属 酸化物種は, $\mathrm{ZnO}, \mathrm{MgO}, \mathrm{In}_{2} \mathrm{O}_{3}, \mathrm{SnO}_{2}, \mathrm{Ga}_{2} \mathrm{O}_{3}$ の 5 種類に 限定されていた。しかしながら, エキゾチックな金属酸 化物材料ならではの特徵的な機能物性（高温超電導・強 磁性・強誘電性・金属絶縁体転移・メモリス夕物性等) は他の金属元素（特に, 遷移金属元素）から構成される 金属酸化物材料において発現する。したがって, 上述し たVLS 法の金属酸化物材料に対する限界を打破して, これらの機能性金属酸化物材料から構成される高品質な 単結晶ナノワイヤをVLS 法により実現する意義や波及 効果は計り知れない。

VLS 法では気体・液体・固体の三相に跨る複雑な物

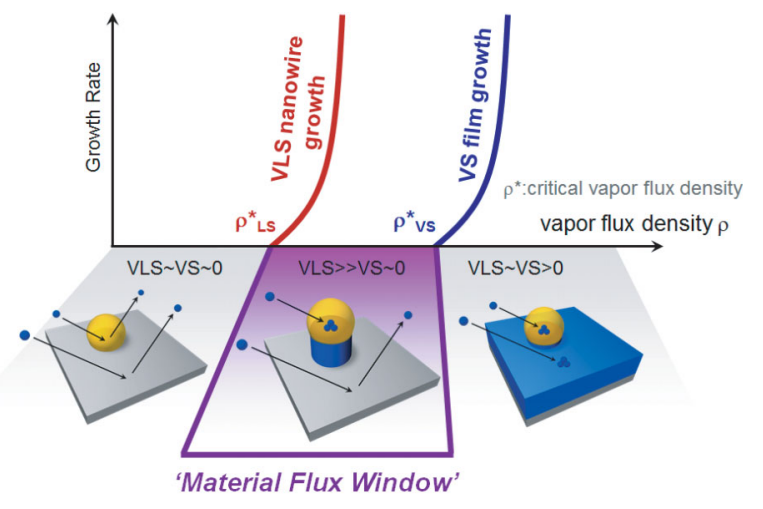

Fig. 1. (color online). Material flux window principle for VLS process. ${ }^{8)}$

質移動現象に基づいた動的非平衡プロセスを制御する必 要がある。温度 - 圧力 ・ 原料ガス供給量 - 酸素分圧 ・ 触 媒サイズ・触媒間距離等の制御因子と自己組織化形成メ カニズムの相関性を理解することにより初めて高度に形 状が規定された単結晶酸化物ナノワイヤ構造体の形成が 可能となる。検討を進めていくうちに, VLS 法の適用 が容易な 5 種類の金属酸化物材料には, 金属元素の蒸気 圧が高いという共通点があることに気付いた。すなわ ち,これらの材料では供給した金属種の固化（すなわち 薄膜構造化）を防ぐことが比較的容易であると言い換え ることもできる。VLS 法では, 液化した金属触媒と固 体との固液界面においてのみに結晶成長が発現する必要 があり, 上記物性の共通点は気固界面における結晶成長 を如何に防ぐかという問題提起であり，VLS ナノワイ ヤ成長と同時に進行する VS（Vapor-Solid）薄膜成長を 如何に制御するかがナノワイヤ形成の重要な鍵となる。 言い換えれば, 薄膜が形成しない実験条件を探し出すこ とが必要となる。分子動力学法を用いた数值計算と実験 との比較検討から ${ }^{25,26)}$, 固液界面における結晶成長が絶 対選択的に生じるメカニズムが, 固液界面における結晶 成長に関するエネルギーバリアが気固界面におけるエネ ルギーバリアと比較して小さくなっており，これが金属 触媒との相互作用に起因していることを明らかにしてき た。Fig. 1 の模式図 ${ }^{8)}$ に示すように，この知見は新しい 機能材料を単結晶ナノワイヤ構造化する際には, これま でに重要視されてきた熱力学的パラメー夕（温度・圧力 等）に加えて, 従来は成長速度のみに影響を与えると信 じられてきた供給フラックスを精密に制御することが固 液界面に絶対選択的に結晶成長を発現させるきわめて重 要な材料設計指針であるとの結論に達するに至った。こ のナノワイヤ材料設計指針は, Fig. 2 に示すように, 既 存の VLS プロセスによって形成される金属酸化物ナノ 

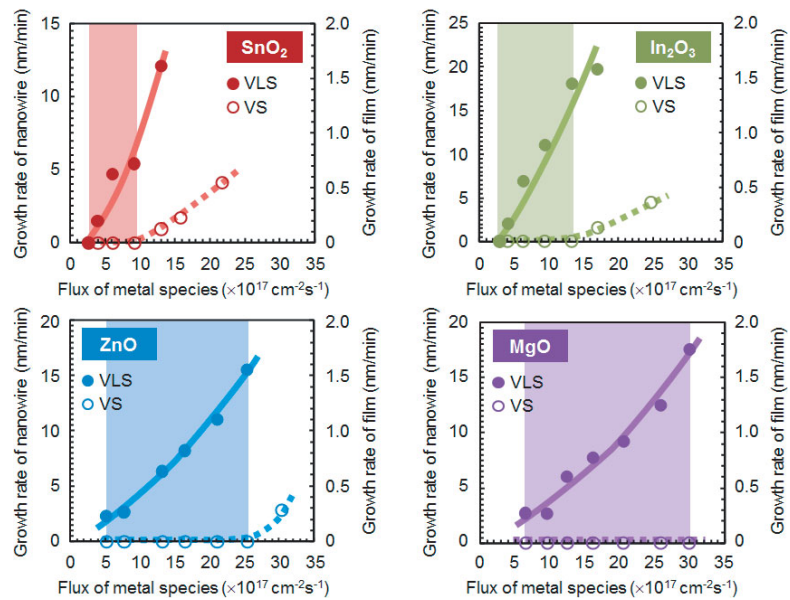

Fig. 2. (color online). Applicability of "material flux window” for VLS nanowire growths of $\mathrm{SnO}_{2}, \mathrm{In}_{2} \mathrm{O}_{3}, \mathrm{ZnO}$ and $\mathrm{MgO}{ }^{8)}$

ワイヤの形成プロセスをすべて説明できることがわかっ た。より具体的には, 供給フラックスの小さい領域では 相対的にVLS 成長が VS 成長に対して優勢になり（VS 成長がほとんど起こらない), ナノワイヤの成長が促進 される ${ }^{8)}$ 。

さらに,このVLS ナノワイヤ結晶成長に求められる 供給フラックス領域 (material flux window) が, 金属酸 化物材料の融点という基礎的な物性と相関していること が明らかになった (Fig. 3 $)^{8)}$ 。MD 計算と古典核生成理 論との比較検討により ${ }^{25,26)}$, この材料依存性が VS 界面 と LS 界面における表面張力の差異に起因していること が判明した。この単結晶ナノワイヤ設計指針に立脚した 供給フラックスの精密制御が可能な実験系を用いて, 従 来技術では不可能であった機能性金属酸化物材料 ( $\mathrm{NiO}, \mathrm{CaO}$ 等) の単結晶ナノワイヤ構造化に成功し た ${ }^{8)}$ 。加えて, 上記知見を結晶成長界面の制御へと展開 することにより，コアシェル構造や超格子構造をナノワ イヤ構造に内包したへテロナノワイヤを設計することが 可能になっている。 $\left(\mathrm{MgO}+\mathrm{TiO}_{2}{ }^{6)}, \mathrm{MgO}+\mathrm{NiO}^{10,11)}\right.$, $\mathrm{MgO}+\mathrm{CoO}^{12,13)}$ 等) この結晶成長界面の制御は Fig. 1 に 示される指針に従って, 供給フラックスを結晶成長中に 変調させることによって実現される。より具体的には, 軸方向へのへテロ構造のためには, 供給フラックスを material flux window 内で変調させ, 半径方向へのへテロ 構造を形成するためには, 供給フラックスを意図的に増 加させることが求められる。Fig. 1 に示した異方性結晶 成長の設計指針は, 本稿で紹介している VLS 結晶成長 プロセスのみならず，より普遍的に適用可能であること が, 溶液中の水熱合成法への適用性から確認されてい

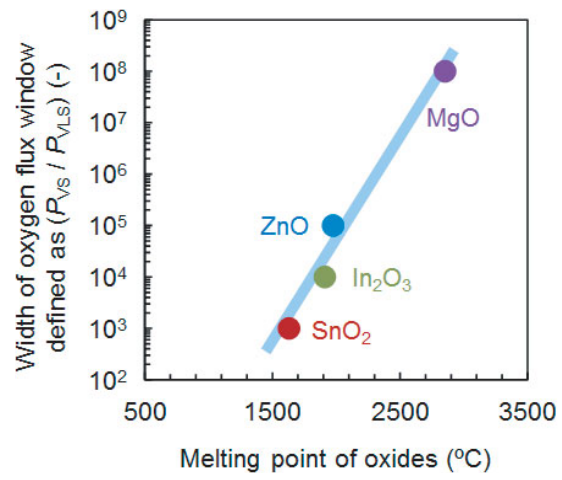

Fig. 3. (color online). Correlation between the width of "material flux window" of oxygen flux and melting point of metal oxides. ${ }^{8)}$

る7)。加えて, MD 計算において温度を変調した数值実 験を行ったところ, 供給フラックスを減少させることで ナノワイヤ成長温度の低減が可能であることがわかっ た。実験系において，本知見を検証したところすべての 金属酸化物ナノワイヤの VLS 結晶成長温度を大幅に低 減することが可能であることを実証した9)。このよう に, 我々の研究グループは, VLS 法を介して単結晶金 属酸化物ナノワイヤが形成される結晶成長プロセスを原 子・分子レベルの観点で解明し, 結晶成長の選択性の本 質的なメカニズムに基づいて構築された新しい実験系に より, 従来技術では困難であった機能性金属酸化物材料 の単結晶ナノワイヤ構造化と結晶成長界面を制御したへ テロナノワイヤ構造の創製に成功した。

\section{3. 単結晶金属酸化物ナノワイヤの物性評価}

1 本の単結晶金属酸化物ナノワイヤの電気・熱物性を 測定するシステムを構築した。電気物性測定に関して は, 金属電極とナノワイヤ間の接触抵抗低減化を図ると ともに, 4 端子測定 ${ }^{17)}$, 電界効果トランジス夕測定 ${ }^{13,19)}$, 熱起電力測定 ${ }^{19)}$ を行うことで, 電気伝導度, キャリアタ イプ, 移動度, キャリア密度, ゼーベック係数を測定す ることを可能にした。これらの測定は, $\mathrm{SiO}_{2} / \mathrm{Si}$ 基板上 において，リソグラフィー手法を適用することによっ て，単一のナノワイヤに金属電極を架橋することで実現 している。熱伝導率測定に関しては, 電気物性測定と大 きく異なる点として, 基板への熱流出がある。この効果 を低減するために, Fig. 4 に示すようなフリースタンデ イング構造を用いた $3 \omega$ 法を適用することで, 一本のナ ノワイヤの熱伝導率測定が可能になっている ${ }^{24)}$ 。

\section{4. ナノワイヤメモリスタ}

$10 \mathrm{~nm}$ 級の金属酸化物ナノワイヤ構造体を用いてシリ 


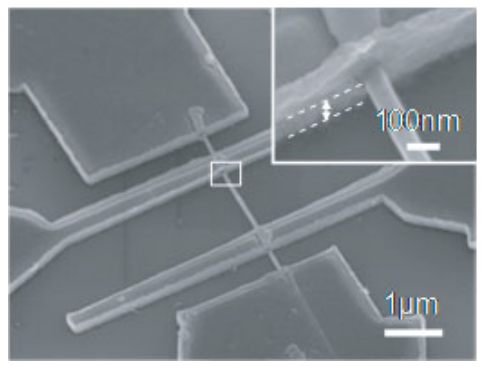

Fig. 4. (color online). SEM image of fabricated single $\mathrm{SnO}_{2}$ nanowire device for thermal conductivity measurements and sensor applications. ${ }^{24)}$

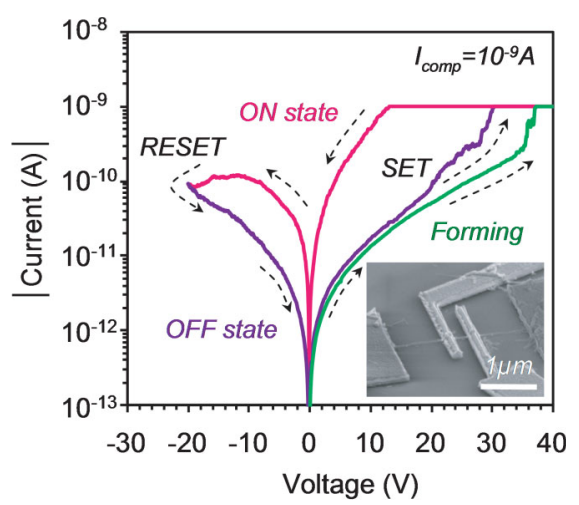

Fig. 5. (color online). Memristive characteristics of a single cobalt oxide nanowire device. ${ }^{12)}$

コン基板上でプレーナー型メモリスタデバイスを構築す ることにより, 従来薄膜素子では固体内部に潜んでいた 不揮発性メモリ現象のメカニズムについて検証した結果 について紹介する ${ }^{10 \sim 16)}$ 。素子を用いて得られた電流-電 圧特性を Fig. 5 に示す。初期状態が高抵抗であるナノワ イヤ素子に電界を印加すると $35 \mathrm{~V}$ 付近でソフトな絶縁 破壊を示唆する急激な電流值の上昇が見られた。Compliance current により素子に流れる電流を $\mathrm{nA}$ 程度に制限 すると, 電圧印加により電気抵抗が可逆的に変化する抵 抗スイッチング効果が観測された。正方向の電界印加に より高抵抗 (OFF) 状態から低抵抗 (ON) 状態へと変 化し, 負方向の電界印加により低抵抗状態から高抵抗状 態へ変化した。以降, $\mathrm{OFF} \rightarrow \mathrm{ON}$ の過程を $\mathrm{SET}, \mathrm{ON} \rightarrow$ OFF の過程を RESET と呼ぶことにする。ナノワイヤ素 子構造の対称性から正負の電圧極性は任意に定義可能で あるが, 初期の Forming と呼ばれる絶縁破壊過程と SET は同じ電圧極性で行われると定義する。抵抗変化には両 極性を必要とし, ON, OFF の両状態は電界不印加下で も維持されることから, ナノワイヤ素子で観測されたこ の現象はバイポーラ型の不揮発性抵抗変化メモリ効果で
あることが明らかとなった。メモリス夕動作には正負ど ちらか一方の電圧極性で駆動するユニポーラ型と本結果 のように両極性を必要とするバイポーラ型が存在する が, 以降の議論をバイポーラ型に基づいて進めていく。 ナノワイヤ素子において, メモリ駆動に必要な電界強度 は従来のキャパシタ型薄膜素子と同程度であることか ら, ナノワイヤ素子で得られた伝導特性は薄膜素子中に 発生するナノスケール伝導パスと同様のものであること が示唆され，同時に $10 \mathrm{~nm}$ スケールにおいてもメモリ ス夕動作が原理的に可能であることが明らかとなった。 作製されたナノワイヤ素子において，1 億回以上の安定 した繰り返し耐性が観測された。このように, $10 \mathrm{~nm}$ 級 のサイズにおいて, きわめて安定な繰り返し耐性と高密 度化を可能とする多值化動作が可能であることを実証し た ${ }^{12)}$ 。

プレーナー型ナノワイヤメモリスタ素子では, 伝導パ スの形成が面内で生じ, 加えてナノワイヤ中に制限され ているため, 従来薄膜キャパシ夕構造では困難であった ナノ伝導パスの直接的・空間的な評価が可能である ${ }^{13)}$ 。 たとえば，これまでにジュール熱による効果と電界によ る効果の競合現象が議論の対象になっていたが, これら 両因子を実験的に区別することは困難であった。我々は ナノワイヤ素子の規定されたナノ制限空間においてこれ らの因子を区別することを試みた。我々の素子では電流 変化幅》電圧幅であったことから, ジュール熱効果（電 力）では主に電流が, 電界効果では電圧が支配的な因子 であると示唆される。SET 電流-RESET 電流には有意な 相関性が見られなかったが，一方で SET 電圧-RESET 電 圧では強い相関性が確認された。SET 過程で印加電界 を増加させると, RESET 過程ではこの増加に相当する 印加電界強度が必要となることを意味している。したが って, 本結果よりバイポーラメモリス夕動作は電界誘起 現象であり, 電界が本現象の制御因子であることが明ら かとなった。

上記の検討において, 検討されたすべてのナノワイヤ 素子においてバイポーラ型のメモリス夕現象が観察され た。従来の知見では, メモリス夕動作においてバイポー ラ型とユニポーラ型がなぜ混在するのかについて明確な デバイス設計指針は得られていなかった。そこで, 我々 は素子のサイズが上記メモリス夕動作のバイポーラ型・ ユニポーラ型に与える影響を, Fig. 6 に示すように幅広 いサイズレンジにおいて検討した ${ }^{18)}$ 。その結果, 素子の サイズがバイポーラ型とユニポーラ型のメモリスタ動作 において決定的な役割を果たしていることが明らかにな った。図に見られるように, 素子に加える電界強度を強 くすると, non-memory $\rightarrow$ bipolar memory $\rightarrow$ unipolar 
a

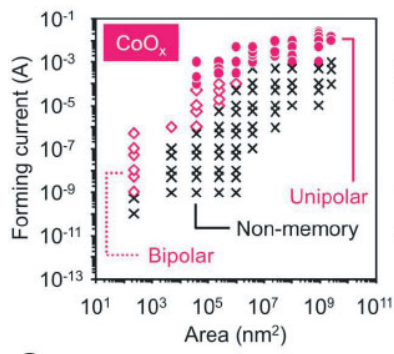

C

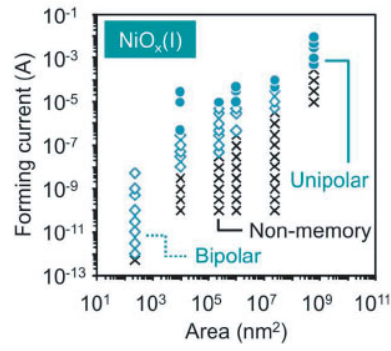

b

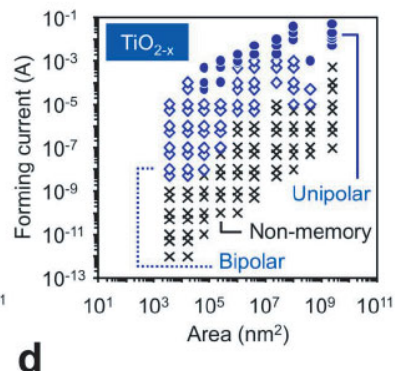

d

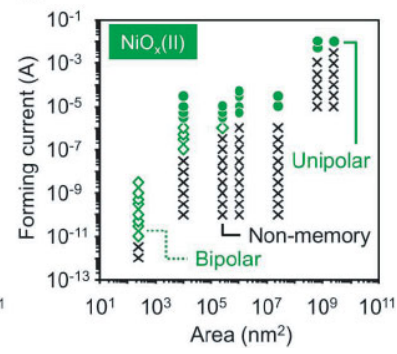

Fig. 6. (color online). (a) Diagram as to variation of polarity characteristics in switching behaviors for CoO. (b) Diagram as to variation of polarity characteristics in switching behaviors for $\mathrm{TiO}_{2}$. (c) and (d) Diagrams as to variations of polarity characteristics in switching behaviors for $\mathrm{NiO}$. The data of two different $\mathrm{NiO}$ layers were shown when changing the deposition conditions of $\mathrm{NiO}$ layers. ${ }^{18)}$

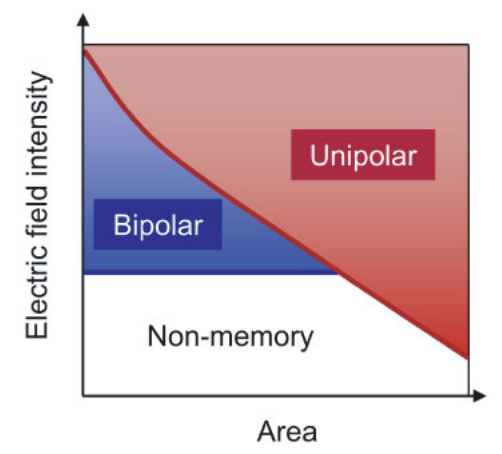

Fig. 7. (color online). Schematic of the emergence of the two polarity characteristics in terms of a diagram between a cell area and an electric field intensity. ${ }^{18)}$

memory と同一素子でメモリ動作の変調が観察された。 また, それらの変調が生じる臨界電界強度が顕著な素子 サイズ依存性を示すことが明らかになった。これらの結 果に基づき, ユニポーラ型とバイポーラ型が様々なデバ イス中で混在するメカニズムに関するモデルを Fig. 7 に 示すように提唱した。

\section{5. 単結晶ナノワイヤの熱電素子，生体分子分 析デバイス, 分子認識センサへの展開}

単結晶ナノワイヤ一本の熱起電力を測定することによ り, その熱電性能を検証した ${ }^{19)}$ 。使用したナノワイヤは VLS 法を介して形成された B をドープした Si ナノワイ ヤである。前章で述べたように, VLS 法ではドーパン トの結晶中への取り込まれる界面が二つ存在する。（液 固界面, 気固界面）ドーパント原子が結晶中への取り込 まれるプロセスが異なることにより，意図しない不純物 ドーパントの空間不均一性が生まれる。均一な半導体于 ヤネルという観点では好ましくないと考えられていた不 純物ドーパントのこの空間不均一性が，ナノワイヤ中の 不純物ドーパントの空間的な不均一性とともに Modulation Doping 効果を生み出し, 熱電変換効率の指標とな る Power Factor を増強することが明らかになってい る ${ }^{19)}$ 。

VLS 法の特徵を活かして, マイクロ流路中の空間中 の狙った位置に望みの表面を有するナノワイヤ構造を形 成した ${ }^{20 \sim 23)}$ 。このナノワイヤ搭載型マイクロ流路デバ イスが DNA, RNA, タンパク質, エクソソーム（癌マ ーカー）を高速で分離・分離する能力を有していること が明らかとなった。本アプローチでは, マイクロ流路中 の狙いの空間位置に, 狙いの表面を有する 3 次元ネット ワーク構造を形成することが可能になっており，この比 較的剛直な 3 次元ネットワーク構造と分子との相互作用 が重要な役割を果たしている。

ナノワイヤ素子において, ナノスケールで熱を制御す る手法を導入することで, 従来技術より消費エネルギー を 9 桁程度低減した分子センサを実証した ${ }^{24)}$ 。本手法の キーとなるものは, (1)パルス自己加熱機構（センサ部と ヒータ部の間隔の最小化), (2)バルクよりも小さなナノ ワイヤ熱伝導率 (熱を閉じ込める効果), (3)小さな熱容 量に起因するマイクロ秒レンジのナノワイヤ熱緩和時間 である。

\section{6. ま め}

本稿では，表面における分子の空間選択性に立脚した 金属酸化物材料から構成される単結晶ナノワイヤの創製 と, それらのナノ構造を機能性デバイスへと展開する筆 者らの最近の研究成果を紹介した。現在では, 所望の機 能性酸化物材料を単結晶ナノワイヤやへテロナノワイヤ 構造として形成することが可能になっており, 今後これ らの新しい単結晶ナノワイヤ構造を活用したデバイス開 発の進展が期待される。金属酸化物は本質的に大気や水 との相性が良く, これまでに研究が進んでいる化合物半 
導体ナノワイヤと比較しても，その“違い”や“個性” を引き出した機能デバイスが世界中から IoT 時代に向け て提案されつつあり, 今後のさらなる進展が期待され る。

\section{謝 辞}

本研究の遂行にあたって共同研究をさせて頂いた，大 阪大学産業科学研究所 川合知二特任教授, 田中秀和教 授, 谷口正輝教授, 筒井真楠准教授, 神吉輝夫准教授, 横田一道助教, 名古屋大学工学研究科 馬場嘉信教授, 加地範匡准教授, 安井隆雄助教, 慶応大学理工学部 内 田建教授, 高橋綱已助教 (現, 九州大学先導物質化学研 究所), 東京大学総合文化研究科 寺尾潤教授, 京都大 学工学研究科 関修平教授, NIMS 深田直樹博士に心 より御礼申し上げます。また，ともに研究を行って頂い たメンバーである九州大学先導物質化学研究所 金井真 樹博士, 鈴木将博士, He Yong 特任助教, Mickaël Boudot 博士, 安西宇宙氏, Zhu Zetao 氏, Chinese Academy of Sciences $の$ Prof. Gang Meng, Huazhong University of Science and Technology の Prof. Fuwei Zhuge, King Mongkut's Institute of Technology の Dr. Sakon Rahong, imec の Dr. Umberto Celano, NANOTEC, Thailand の Dr. Annop Klamchuen, NECTEC, Thailand の Dr. Mati Horprathum, Nanjing University の Dr. Bo Xu, ソニー株式 会社の岡敬祐博士, NILPRF の Dr. Aurelian Marcu に心 より御礼申し上げます。

\section{文献}

1) P. Yang, M. Fardy and R. Yan : Nano Lett. 10, 1529, (2010).

2) R.S. Wagner and W.C. Ellis : Appl. Phys. Lett. 4, 89 (1964).

3) K. Nagashima, T. Yanagida, H. Tanaka and T. Kawai : Appl. Phys. Lett. 90, 233103 (2007).

4) T. Yanagida, A. Marcu, H. Matsui, K. Nagashima, K. Oka, K. Yokota, M. Taniguchi and T. Kawai : J. Phys. Chem. C 112, 18923 (2008).

5) A. Klamchuen, T. Yanagida, K. Nagashima, S. Seki, K. Oka, M. Taniguchi and T. Kawai : Appl. Phys. Lett. 95, 053105 (2009).

6) K. Nagashima, T. Yanagida, H. Tanaka, S. Seki, A. Saeki, S. Tagawa and T. Kawai : J. Am. Chem. Soc. 130, 5378 (2008)

7) Y. He, T. Yanagida, K. Nagashima, F. Zhuge, G. Meng, B. Xu, A. Klamchuen, S. Rahong, M. Kanai, X. Li, M. Suzuki, S. Kai and T. Kawai : J. Phys. Chem. C 117, 1197 (2013).

8) A. Klamchuen, A.M. Suzuki, K. Nagashima, H. Yoshida, M. Kanai, F.W. Zhuge, Y. He, G. Meng, S. Kai, S. Takeda, T. Kawai and T. Yanagida : Nano Lett. 15, 6406
(2015).

9) Z. Zhu, M. Suzuki, K. Nagashima, H. Yoshida, M. Kanai, G. Meng, H. Anzai, F.W. Zhuge, Y. He, M. Boudot, S. Takeda and T. Yanagida : Nano Lett. 16, 7495 (2016).

10) K. Oka, T. Yanagida, K. Nagashima, H. Tanaka and T. Kawai : J. Am. Chem. Soc. 131, 3434 (2009).

11) K. Oka, T. Yanagida, K. Nagashima, T. Kawai, J.-S. Kim and B.H. Park : J. Am. Chem. Soc. 132, 6634 (2010).

12) K. Nagashima, T. Yanagida, K. Oka, M. Taniguchi, T. Kawai, J.-S. Kim and B.H. Park : Nano Lett. 10, 1359 (2010).

13) K. Nagashima, T. Yanagida, K. Oka, M. Kanai, A. Klamchuen, J.-S. Kim, B.H. Park and T. Kawai : Nano Lett. 11, 2114 (2011).

14) K. Oka, T. Yanagida, K. Nagashima, T. Kawai, J.-S. Kim and B.H. Park: J. Am. Chem. Soc. 133, 12482 (2011).

15) K. Oka, T. Yanagida, K. Nagashima, M. Kanai, B. Xu, BH. Park, H. Yoshida and T. Kawai : J. Am. Chem. Soc. 134, 2535 (2012).

16) K. Nagashima, T. Yanagida, K. Oka, M. Kanai, A. Klamchuen, S. Rahong, G. Meng, M. Horprathum, B. Xu, F. Zhuge, Y. He, B.H. Park and T. Kawai : Nano Lett. 12, 5684 (2012).

17) G. Meng, T. Yanagida, K. Nagashima, H. Yoshida, M. Kanai, A. Klamchuen, F. Zhuge, Y. He, S. Rahong, X. Fang, S. Takeda and T. Kawai : J. Am. Chem. Soc. 135, 7033 (2013).

18) T. Yanagida, K. Nagashima, K. Oka, M. Kanai, A. Klamchuen, B.H. Park and T. Kawai : Sci. Rep. 3, 1657 (2013).

19) Z. Fuwei, T. Yanagida, N. Fukata, K. Uchida, M. Kanai, K. Nagashima, G. Meng, Y. He, S. Rahong, X. Li and T. Kawai : J. Am. Chem. Soc. 136, 14100 (2014).

20) T. Yasui, S. Rahong, K. Motoyama, T. Yanagida, Q. Wu, N. Kaji, M. Kanai, K. Doi, K. Nagashima, M. Tokeshi, M. Taniguchi, S. Kawano, T. Kawai and Y. Baba: ACS Nano 7, 3029 (2013).

21) A. Klamchuen, H. Tanaka, D. Tanaka, H. Toyama, G. Meng, S. Rahong, K. Nagashima, M. Kanai, T. Yanagida, T. Kawai and T. Ogawa: Adv. Mater. 25, 5893 (2013).

22) S. Rahong, T. Yasui, T. Yanagida, G. Meng, F. Zhuge, Y. He, N. Kaji, M. Kanai, K. Nagashima, T. Kawai and Y. Baba : Sci. Rep. 4, 5252 (2014).

23) S. Rahong, T. Yasui, T. Yanagida, K. Nagashima, M. Kanai, G. Meng, Y. He, F.W. Zhuge, N. Kaji, T. Kawai and Y. Baba: Sci. Rep. 5, 10584 (2015).

24) G. Meng, F.W. Zhuge, K. Nagashima, A. Nakao, M. Kanai, Y. He, M. Boudot, T. Takahashi, K. Uchida and T. Yanagida: ACS Sensors 1, 997 (2016).

25) M. Suzuki, Y. Hidaka, T. Yanagida, M. Kanai, T. Kawai and S. Kai : Phys. Rev. E 82, 011605 (2010).

26) M. Suzuki, Y. Hidaka, T. Yanagida, A. Klamchuen, M. Kanai, T. Kawai and S. Kai : Phys. Rev. E 83, 061606 (2011). 